\title{
Financial Stability and Prudential Requirements in Tunisian Case
}

\author{
Inene Kanzari ${ }^{1}$, Mraihi Fayçal ${ }^{1}$ \\ ${ }^{1}$ Higher School of Economic and Commercial Sciences of Tunis, Tunisia \\ Correspondence: Inene Kanzari, Higher School of Economic and Commercial Sciences of Tunis, Tunisia. \\ Received: June 12, 2017 \\ doi:10.5539/ibr.v10n10p126 \\ Accepted: September 11, $2017 \quad$ Online Published: September 22, 2017 \\ URL: https://doi.org/10.5539/ibr.v10n10p126
}

\begin{abstract}
This paper has as object the study of the effects of prudential regulation on the financial stability. Using panel data, we select a sample of Tunisian bank over the period 1996-2014. The findings show the significant and negative effect of capital requirements.
\end{abstract}

\section{JEL classification: G01, G21, G28}

Keywords: prudential regulation, financial stability, Z-score, panel data

\section{Introduction}

Financial stability is still a preoccupation of the international financial regulatory authorities because of its importance in a healthy and regular economic development process. It is frequently defined by the absence of instability of the financial system which, through the increased interconnection of its different components, has become more exposed to destabilizing problems such as risks and crises.

The financial stability, necessary for the economic growth, affects the financial institutions. It presents a great importance for the financial system.

The regulatory and prudential frameworks are renovated by passing from Basel I to Basel II and Basel III, aimed at strengthening the stability and thereby enhancing the resilience of domestic and international financial systems to shocks and crises. The financial institutions have to respect the dictated and mandatory rules.

The period, beginning of 2007 until today, is marked by a cascade of difficulties at national and international level. The economic situation is affected by the financial crisis of subprime, without neglecting the series of revolutions which knew the world and the European crisis, in particular, the sovereign debt such as in Italy and in Greece.

Further to the crisis, it was imperative to strengthen and to deepen the statutory standards in terms of regulatory capital and this because of its insufficiency during the disturbances, to face the shocks which affected the financial system.

The international authorities of regulation, through Basel III, imposed more demanding standards and coverage, in front of multiple risks and a more explicit supervision by macro-prudential means.

The international adoption of the Basel I and Basel II Capital Adequacy or Minimum Capital Requirements is one of the key financial innovations known by the Banking sector since the nineties. With Basel III, the new standardization guidelines are being applied in many countries. According to the latter guidelines, financial stability can be ensured by both micro and macro-prudential approaches. Indeed, the macro-prudential approach focuses on systemic risks and their emergence, while the micro-prudential approach focuses on individual risks, particularly those of banks. The solvency of banking and financial institutions worries international financial authorities which seek a certain degree of risks control, mainly credit, market and operational ones.

In this context, the objective of our study is to identify the nature of the relationship between regulation and stability. It is organized as follow. In section 2, we present a literature review. Section 3 explains empirical methodology: the selected variables and the model used. In section 4, we report results and interpretation.

\section{Literature Review}

According to Shrieves and Dahl (1992) who examined the effect of capital regulation on risk, by studying a sample of US commercial banks for the period 1983-1987, regulatory pressure can contribute to increase the level of capital and limiting bank risk taking. 
Following Jacques and Nigro (1997), Kendall and Levonian (1992), the rule of regulatory norms designed to minimize the probability of bankruptcy obliges banks to choose high-risk assets. Blum (1999) suggests, within a dynamic framework, that capital adequacy rules may increase the bank risk: the ability to increase equity tomorrow supposes the increase of the risk today.

The aim of Murinde and Yaseen (2004) study was to analyze the impact of the Basel Accord on banking capital and risk levels in the Middle East and North Africa (MENA) regions for the period 1995 - 2003. They concluded that "capital adequacy" and regulatory pressure have positively affected the level of risk.

Agoraki and al (2011) have argued that the stabilizing effects of prudential capital adequacy regulation decline when banks have sufficient market power to increase their credit risk.

According to Hakenes and Schnabel (2011), the capital requirements effect on the financial stability is ambiguous. This ambiguity is translated by the competition impact on the banking risk management problem. On the basis of a theoretical model, the authors concluded that the regulations in terms of capital can destabilize the banking sector.

Demirgue and Detragiache (2011) reported, on the basis of a sample of multi countries banks, that Basel regulation was not robustly associated with risk measured by z-score reflecting the stability. Agénor, Alper and Da Silva (2011) analysis based on a dynamic stochastic model, examined bank capital regulation roles in mitigating and promoting financial stability: a Basel III capital regulation may be optimal for promoting stability.

Miklaszewska and al (2012) study, by assessing the regulation impact on bank stability, has showed a decline in this stability during the financial crisis. According to Thakor (2014), capital requirements are relied upon as a source of individual bank safety and, through the contagion argument, of financial system.

De Souza (2014) study that simulated changes in capital requirements effects on the Brazilian system, showed that large increases in the delinquency rate lead to only modest losses in the system.

Similar to Agoraki and al (2011) who noticed the existence of a relation between the requirement of capital and the stability, Hogan (2015) examined the link between the prudential regulation and the insolvency risk of the American banks from 1999 to 2010.

As for Hoque and al (2015), they tried to verify if the prudential regulations manage to reduce the banking risk during a crisis by studying the case of banks at the world level at the end of 2007. The authors showed that the regulatory restrictions are negatively related to the distance from the default. Regulation seems an effective reducing means of insolvency risk and risk in general.

Matynova (2015) advanced that the Basel III argument is the financial stability promotion. Prudential regulation may affect stability by reducing ex-ante incentives to take risk. Cecchetti (2015) summarized the regulatory changes implemented over the past years: as a result of Basel III standards, the financial system is substantially safer but this is not enough.

\section{Methodology}

On the basis of the previous studies, we noticed the existence of a set of indicators which can have implications on the financial stability with an emphasis on the banking sector. The adequacy in terms of capital constitutes an essential criterion to analyze the stability of banks. Let us remind that the recent reforms of the prudential requirements constitute innovations. So it seems interesting to study their effects on stability.

In our study, we try to verify if the regulation, in terms of capital adequacy under the supervision of the banking activities, affect the banks stability. According to the realized works, banks operating in an environment legally developed and favoring financial innovations could enjoy or not of more stability.

$\mathrm{H}_{0}$ : the regulation has an effect on the banking stability.

\subsection{Indicators Selection}

The z-score became an indicator and a measure of the financial solidity used in previous works studying the notion of the bank stability. We can quote the works of Boyd and Runkle (1993), Laeven and Levine (2009), Uhde and Heimeshoff (2009), Uhde (2011) and Michalack and Uhde (2012), Hao (2013), Lee and Chin (2013), Hoque and al (2015) and Fernandez and al (2016).

The Z-score can be determined by using the default probability proposed by Roy (1952), Blair and Heggestad (1978), Boyd and Graham (1986), Scott (1989) and developed by Goyeau and Tarazi (1992). This probability corresponds to Prob $(\pi<-\mathrm{E})$ : the losses exceed the capital.

Agoraki, Delis and Pasiouras (2011) studied the banking sector of the Eastern Europe over the period 1998-2005 
to analyze the relation between the regulation and the default probability. They used the measure of Z-score which takes into account the banking activities risks and the degree of their capital coverage.

According to Fang and al (2011), Lee and Chin (2013), a high z-score implies a lower probability of insolvency or a lower default risk and a more important financial stability. This measurement indicates the distance from the failure.

Fernandez, Gonzalez and Suarez (2016) and Ashraf, Zheng and Arshad (2016) works are based on the same indicator to measure the bank insolvency risk: as long as this score is raised as long as the bank is stable.

Zscore is equal to $(R O A a+(E / A) a) / \sigma(R O A)$ with ROAa, E, A and $\sigma(\mathrm{ROAa})$ represent respectively: the average return on assets, bank equity, bank assets and volatility of the average return on assets.

Many determinants appear able to explain the stability.

Globally and according to what is suggested by the theoretical and empirical literature, we tried to select a set of variables. We choose the most relevant factors.

Reg: is a variable which reflects the prudential requirement and aims, through the respect of the capital adequacy standards, the banking stability and there the financial stability. Among the measures, we opt for a binary variable: it is equal to 1 if there is no respect for the minimum required by the regulations and 0 otherwise.

According to Donath and Cismas (2008), for financial institutions, financial stability means that they have sufficient capital and liquidity to, respectively, absorb losses, specially, the abnormal ones and to manage the volatility.

Liq: Liquidity ratio is measured by the ratio of realizable assets to liabilities due. A greater liquidity reserve may be associated with a lower risk of insolvency, which confirms the hypothesis of Leaven and Levine (2009).

Cap: The ratio of bank capital. As long as banks are capitalized, as long as they are stable.. We choose this variable according to Ben Salah and Fdhila (2012) and Casu (2012).

Size: The total assets transformed under a logarithmic function. Big banks have more diversification opportunities than small ones. But these same banks, given their activity, probably important in the markets, and their specialization in credit, can be in risky situations. This leads to the assumption of difficulties in ensuring their stability. So we can estimate a positive or negative relationship between size and stability as Agoraki et al (2011).

Npa: The ratio of new provisions to total assets (Fang, Hasan and Marton (2011)). The deterioration in claims and assets in general can lead to a destabilizing situation for banks.

Gdp and Inf: two macroeconomic variables that represent respectively the growth rate of Gdp and the inflation rate. They are introduced by Fang, Hasan and Marton (2011), Michalak and Uhde (2012) and Diaconu and Oanea (2015). It seems interesting to integrate such variables in our analysis. Indeed, Gdp is an indicator of economic activity dynamism and growth. In a recession period, we can see an increase in the risk of non-repayment of bank borrowers with a decrease in consumption and investment. Interest rates tend to rise in periods of inflation; this encourages banks to engage in investments offering opportunities in terms of risky portfolios. But this rates increase causes a difficulty in repaying bank claims, which can affect stability.

\subsection{Models and Descriptive Statistics}

From the above, stability can be studied as a function of the variables cited.

- In a first step, we will analyze the effect of selected variables. We will estimate the model 1:

$$
\text { Zscore }=\alpha_{0}+\alpha_{1} \text { cap }_{i, t}+\alpha_{2} \text { size }_{i, t}+\alpha_{3} l i q_{i, t}+\alpha_{4} n p a_{i, t}+\mu_{i, t}
$$

- In a second step, we will introduce the regulation variable and estimate the model 2:

$$
\text { Zscore }=\alpha_{0}+\alpha_{1} \text { cap }_{i, t}+\alpha_{2} \text { size }_{i, t}+\alpha_{3} \operatorname{liq}_{i, t}+\alpha_{4} n p a_{i, t}+\alpha_{5} \text { reg }_{i, t}+\mu_{i, t}
$$

- In a third step, we will introduce the macroeconomic variables and estimate the model 3:

$$
\text { Zscore }=\alpha_{0}+\alpha_{1} \text { cap }_{i, t}+\alpha_{2} \text { size }_{i, t}+\alpha_{3} \text { liq }_{i, t}+\alpha_{4} n p a+\alpha_{5} \text { reg }_{i, t}+\alpha_{6} g d p_{i, t}+\alpha_{7} \text { inf }_{i, t}+\mu_{i, t}
$$

Our study focuses on a period from 1996 to 2014 and the case of ten Tunisian banks. Note that the Tunisian Central Bank continues the adoption of Base II and prepares all banks for Basel III. We will proceed with a panel data methodology.

On the basis of table 1, we find that the average score of the Tunisian banks constituting our sample is 4.004 with respective maximum and minimum values of 10.166 and -1.2708 . The score is relatively volatile given the level 
of deviation (1.451). Note that due to non-normality of the Z-score distribution, we use a Logarithmic transformation.

The following table presents a descriptive statistics.

Table 1. Descriptive statistics

\begin{tabular}{|c|c|c|c|c|c|}
\hline Variables & Obs & Mean & Std. Dev. & Min & Max \\
\hline lzscore & 190 & 4.004408 & 1.451972 & -1.2708 & 10.166 \\
\hline cap & 190 & .1068474 & .068609 & -.05 & .857 \\
\hline size & 190 & 14.77773 & .6293032 & 13.526 & 15.985 \\
\hline npa & 190 & .0107105 & .0108845 & -.008 & .102 \\
\hline liq & 190 & 1.098772 & .1811495 & .66 & 1.92 \\
\hline reg & 190 & .1842105 & .38868 & 0 & 1 \\
\hline Inf & 190 & .0378947 & .0124207 & .02 & .06 \\
\hline gdp & 190 & .0411474 & .0203317 & -.0192 & .0715 \\
\hline
\end{tabular}

The regulation variable (reg) has an average of 0.1842 and a volatility of 0.388 . As for the variables (cap), (size), (npa) and (liq), they have respective averages of 0.106, 14.777, 0.0107 and 1.098. In terms of volatility, the four measures appear to be less volatile than the score, in particular (cap) and (npa) with de viations of 0.068 and 0.010. As for the average of the macroeconomic variables, we find a value of 0.041 for the GDP rate and 0.037 for inflation. The two rates are not volatile since they show a deviation of 0.020 and 0.012 .

\section{Results and Interpretation}

To study relationships cited, we rely on the panel data method. To account for the two effects fixed effect (I) and random effect (II), we refer to the Hausman test. The estimations give us the following summaries tables (Tables 2).

Table 2. Results

\begin{tabular}{|c|c|c|c|c|c|c|}
\hline \multirow[b]{2}{*}{ Variables } & \multicolumn{2}{|c|}{ Modèle 1} & \multicolumn{2}{|c|}{ Modèle 2} & \multicolumn{2}{|c|}{ Modèle 3} \\
\hline & I & II & I & II & I & II \\
\hline Cap & 1.310 & 1.762 & 0.888 & 0.977 & 0.909 & 1.346 \\
\hline & $(0.83)$ & $(1.19)$ & $(0.56)$ & $(0.65)$ & $(0.58)$ & (0.90) \\
\hline Size & $-0.667 * * *$ & $-0.415^{* *}$ & $-0.751 * * *$ & $-0.503 * * *$ & -0.361 & -0.149 \\
\hline & $(-3.31)$ & $(-2.43)$ & $(-3.71)$ & $(-2.89)$ & $(-1.09)$ & $(-0.66)$ \\
\hline $\mathrm{Npa}$ & $\begin{array}{c}-40.38 * * * \\
(-4.47)\end{array}$ & $\begin{array}{c}-42.02 * * * \\
(-4.63)\end{array}$ & $\begin{array}{c}-38.61 * * * \\
(-4.31)\end{array}$ & $\begin{array}{c}-39.33 * * * \\
(-4.38)\end{array}$ & $\begin{array}{c}-40.28 * * * \\
(-4.47)\end{array}$ & $\begin{array}{c}-41.71 * * * \\
(-4.66)\end{array}$ \\
\hline Liq & $\begin{array}{l}0.272 \\
(0.45)\end{array}$ & $\begin{array}{l}0.771 \\
(1.34)\end{array}$ & $\begin{array}{l}0.307 \\
(0.51)\end{array}$ & $\begin{array}{l}0.694 \\
(1.22)\end{array}$ & $\begin{array}{c}-0.0641 \\
(-0.10)\end{array}$ & $\begin{array}{l}0.257 \\
(0.43)\end{array}$ \\
\hline Reg & & & $\begin{array}{c}-0.616^{* *} \\
(-2.32)\end{array}$ & $\begin{array}{c}-0.614 * * \\
(-2.37)\end{array}$ & $\begin{array}{c}-0.559 * * \\
(-2.04)\end{array}$ & $\begin{array}{c}-0.590 * * \\
(-2.26)\end{array}$ \\
\hline Inf & & & & & $\begin{array}{l}-14.04 \\
(-1.23)\end{array}$ & $\begin{array}{c}-18.42 * \\
(-1.92)\end{array}$ \\
\hline Gdp & & & & & $\begin{array}{l}8.700 \\
(1.38)\end{array}$ & $\begin{array}{l}10.76^{*} \\
(1.93)\end{array}$ \\
\hline Cons & $\begin{array}{c}13.86^{* * * *} \\
(4.34)\end{array}$ & $\begin{array}{c}9.556 * * * \\
(3.47)\end{array}$ & $\begin{array}{c}15.20 * * * \\
(4.74)\end{array}$ & $\begin{array}{c}11.10 * * * \\
(3.96)\end{array}$ & $\begin{array}{c}10.02 * * \\
(2.14)\end{array}$ & $\begin{array}{c}6.593^{* *} \\
(1.97)\end{array}$ \\
\hline Observations & 190 & 190 & 190 & 190 & 190 & 190 \\
\hline Fisher & 8.41 & & 7.97 & & 6.04 & \\
\hline Prob $>F$ & $(0.0000)$ & & $(0.0000)$ & & $(0.0000)$ & \\
\hline Wald Chi2 & & 37.33 & & 43.07 & & 49.77 \\
\hline Prob> Chi2 & & $(0.0000)$ & & $(0.0000)$ & & $(0.0000)$ \\
\hline$R^{2}$ & & & & & & \\
\hline Within & 0.1605 & 0.1497 & 0.1855 & 0.1772 & 0.1964 & 0.1920 \\
\hline Between & 0.1586 & 0.3528 & 0.2112 & 0.3558 & 0.3659 & 0.5774 \\
\hline Overall & 0.1549 & 0.1745 & 0.1797 & 0.1981 & 0.2164 & 0.2305 \\
\hline Hausman test & & 10.24 & & 10.31 & & 5.76 \\
\hline Prob> Chi2 & & $(0.0366)$ & & $(0.0669)$ & & $(0.5918)$ \\
\hline Wooldridge test & 44.689 & & 38.843 & & 48.854 & \\
\hline Prob $>F$ & $(0.0001)$ & & $(0.0002)$ & & $(0.0001)$ & \\
\hline
\end{tabular}

The Hausman test allows us to choose the fixed effect (I) for the first model and the random effect (II) for the others models. We can conclude that all models are globally significant.

We try to apply the heteroskedasticity and the autocorrelation tests. These tests show the absence of heteroskedasticity for all the models but the presence of first order autocorrelation: AR (1) (Wooldridge test). 
Following the corrections carried out, the model estimates give the table 3 results.

Table 3. Results after correction of the first order autocorrelation

\begin{tabular}{|c|c|c|c|}
\hline Variables & Model 1 & Model 2 & Model 3 \\
\hline Cap & $\begin{array}{l}2.243^{*} \\
(1.82)\end{array}$ & $\begin{array}{l}\text { 2.113* } \\
(1.73)\end{array}$ & $\begin{array}{r}2.017 * \\
(1.64)\end{array}$ \\
\hline Size & $\begin{array}{c}-0.423^{*} \\
(-1.69)\end{array}$ & $\begin{array}{c}-0.424 * \\
(-1.73)\end{array}$ & $\begin{array}{l}-0.287 \\
(-1.04)\end{array}$ \\
\hline $\mathrm{Npa}$ & $\begin{array}{l}-23.29 * * * \\
(-3.08)\end{array}$ & $\begin{array}{l}-22.37 * * * \\
(-2.98)\end{array}$ & $\begin{array}{l}-23.18 \text { *** } \\
(-3.08)\end{array}$ \\
\hline Liq & $\begin{array}{l}-0.110 \\
(-0.17)\end{array}$ & $\begin{array}{l}-0.110 \\
(-0.18)\end{array}$ & $\begin{array}{l}-0.244 \\
(-0.38)\end{array}$ \\
\hline reg1 & & $\begin{array}{l}-0.564 * * \\
(-2.30)\end{array}$ & $\begin{array}{l}-0.555^{* * *} \\
(-2.24)\end{array}$ \\
\hline Inf & & & $\begin{array}{l}-4.067 \\
(-0.50)\end{array}$ \\
\hline Gdp & & & $\begin{array}{l}6.309 \\
(1.38)\end{array}$ \\
\hline Cons & $\begin{array}{l}10.37 * * * \\
(2.66)\end{array}$ & $\begin{array}{l}10.50 * * * \\
(2.74)\end{array}$ & $\begin{array}{l}8.520 * * \\
(2.04)\end{array}$ \\
\hline Observations & 190 & 190 & 190 \\
\hline Wald Chi2 & 16.61 & 22.41 & 24.29 \\
\hline $\begin{array}{l}\text { Prob> Chi2 } \\
R^{2}\end{array}$ & $(0.0053)$ & $(0.0010)$ & $(0.0020)$ \\
\hline Within & 0.1466 & 0.1585 & 0.1735 \\
\hline Between & 0.1815 & 0.2950 & 0.3703 \\
\hline Overall & 0.1467 & 0.1723 & 0.1977 \\
\hline
\end{tabular}

$* * * \mathrm{p}<0.01, * * \mathrm{p}<0.05,{ }^{*} \mathrm{p}<0.1$

The application of post-estimate tests seems interesting

Models results 1,2 and 3 show that the quality of assets, exactly the claims, affects negatively and significantly the stability of the studied Tunisian banks. Indeed, a high ratio involves a low quality so more risk and then less stability. This result confirms that of Fang, Hasan et Marton (2011). According to size analysis, the big banks are the least stable. This report is in accordance with that of Agoraki, Delis and Pasiouras (2011). As for the liquidity, it exercises no influence on the stability.

The results of models 2 and 3 show, mainly, the negative and significant effect of the regulation on the stability of banks. Recent years have seen a significant progress in reforms, globally, in order to increase the stability of banking systems. In Tunisia, like all countries looking for a greater stability of its financial system through a solid banking sector, it has implemented reforms aimed mainly at better risk management. The authorities of regulation aiming at a financial system more stable through the capital requirement and the Basel guidelines looked for the adoption of international standards in the national financial situation. Recently a higher capital ratio is required: the minimum capital requirement is raised, by the Tunisian Central Bank, from 5\% to $8 \%$ in 1999 to reach $9 \%$ at the end of 2013 and $10 \%$ at the end of 2014. Such a requirement may, as Kroszner (2012) argued, force banking institutions which seeking to maintain or improve their equity returns, to engage in riskier activities, which can lead to a fragile banking sector and thus a lack of financial stability. Note that Tunisia is characterized by a bank-based system. So the capital adequacy alone not guaranteed a positive impact on the stability. It must be realized in a complete regulation system by integrating other dimensions of the reform, such as the supervision and the anticipation capacity.

As for the capatilization, a significant and positive effect is detected. This result is in accordance with those of Laeven and Levine (2009) and Fdhila (2012) who suggest that the overcapitalized banks seem more stable: they are capable to absorb losses in the case of a financial difficulty

Concerning the rates of the GDP and the inflation, they exercise, respectively, a positive and negative effect on the level of banking stability. This confirms the report of Uhde (2012) and Diaconu and Oanea (2014): an economic growth coincides with an increase at the level of the banking stability.

\section{Conclusion}

Our work aimed at studying stability has reached to select a set of variables and measures that can affect the probability of default and the risk of insolvency. It concludes, for the case of Tunisian banks over the period 1996-2014, the negative impact of the capital requirements. So the capital adequacy alone not guaranteed a positive impact on the stability. 


\section{References}

Akhigbe \& Whyte. (2001). The impact of FDICIA on bank returns and risk: evidence from the capital markets. Journal of banking \& finance, 25(2), 393-417. https://doi.org/10.1016/S0378-4266(99)00131-4

Ashraf, B. N. et al. (2016). Effects of National Culture on Bank Risk-taking Behavior. Research in International Business and Finance, 37. https://doi.org/10.1016/j.ribaf.2016.01.015

Awdeh, et al. (2011). The effect of capital requirements on banking risk. International Research Journal of Finance and Economics, 66, 133-146.

Binder. (1998). The e vent study methodology since 1969. Review of quantitative Finance and Accounting, 11(2), 111-137. https://doi.org/10.1023/A:1008295500105

Blum. (1999). Do capital adequacy requirements reduce risks in banking? Journal of banking \& finance, 23(5), 755-771.

Bougatef \& Mgadmi, (2016). The impact of prudential regulation on bank capital and risk-taking: The case of MENA countries. The Spanish Review of Financial Economics.

Corrado. (2011). Event studies: A methodology review. Accounting \& Finance, 51, 207-234. https://doi.org/10.1111/j.1467-629X.2010.00375.x

Diaconu \& Oanea. (2014). The main determinants of bank's stability. Evidence from Romanian banking sector. Procedia Economics and Finance, 16, 329-335. https://doi.org/10.1016/S2212-5671(14)00810-7

Diaconu \& Oanea. (2015). Determinants of bank's stability. Evidence from creditcoop. Procedia Economics and Finance, 32, 488-495. https://doi.org/10.1016/S2212-5671(15)01422-7

Donath \& Cismas. (2008). Determinants of financial stability. The Romanian economic Journal, 29.

Fang, et al. (2011). Market reforms, legal changes and bank risk-taking-evidence from transition economies. Bank of Finland Research Discussion Paper, 7. https://doi.org/10.2139/ssrn.1805565

Fernández, et al. (2016). Banking Stability, Competition, and Economic Volatility. Journal of Financial Stability. https://doi.org/10.1016/j.jfs.2016.01.005

Hakenes \& Schnabel. (2011). Capital regulation, bank competition, and financial stability. Economics Letters 113, 256-258. https://doi.org/10.1016/j.econlet.2011.07.008

Hoque, et al. (2015). Bank regulation, risk and return: Evidence from the credit and sovereign debt crises. Journal of banking \& finance, 50, 455-474. https://doi.org/10.1016/j.jbankfin.2014.06.003

Kahane. (1977). Capital adequacy and the regulation of financial intermediaries. Journal of banking and finance 1, 207-218. https://doi.org/10.1016/0378-4266(77)90007-3

Laeven, L., \& Le vine, R. (2009). Bank governance, regulation and risk taking. Journal of Financial Economics, 93(2), 259-275. https://doi.org/10.1016/j.jfineco.2008.09.003

MacKinlay. (1997). Event studies in economics and finance. Journal of economic literature, 35, 13-39.

Percuin \& Dodon. (2014). Financial stability of the republic of Moldova estimated through monetary indicators. Journal of financial and monetary economics, 1, 125-130.

Sironi \& Zazzara. (2003). The Basel Committee proposals for a new capital accord: implications for Italian banks. Review of financial economics, 12, 99-126. https://doi.org/10.1016/S1058-3300(03)00009-0

Uhde \& Michalak. (2010). Securitization and systematic risk in European banking: Empirical evidence. Journal of banking \& finance, 34, 3061-3077. https://doi.org/10.1016/j.jbankfin.2010.07.012

Uhde, et al. (2012). Wealth effects of credit risk securitization in European banking. Journal of Business Finance \& Accounting, 39, 193-228. https://doi.org/10.1111/j.1468-5957.2012.02273.x

\section{Copyrights}

Copyright for this article is retained by the author(s), with first publication rights granted to the journal.

This is an open-access article distributed under the terms and conditions of the Creative Commons Attribution license (http://creativecommons.org/licenses/by/4.0/). 